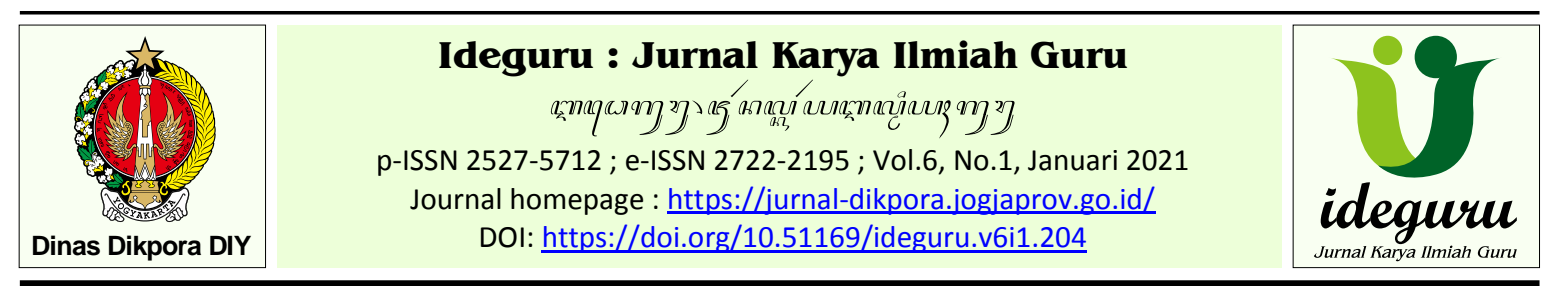

Best Practice - Naskah dikirim: 12/01/2021 - Selesai revisi: 09/02/2021 - Disetujui: 12/02/2021 - Diterbitkan: 15/03/2021

\title{
Optimalisasi Pembelajaran Jarak Jauh pada Pelajaran Prakarya dengan Penerapan Blended Learning melalui Kegiatan Tilik Siswa
}

\author{
Susi Prasetyaningtyas \\ SMP Negeri 1 Semin \\ susi.espensa@gmail.com
}

\begin{abstract}
Abstrak: Tujuan best practise ini untuk mengoptimalkan pembelajaran jarak jauh melalui kegiatan tilik siswa, mengevaluasi pelaksanaan kegiatan tilik siswa, dan mendeskripsikan kendala dan solusi pada pembelajaran jarak jauh melalui kegiatan tilik siswa. Subjek best practise ini adalah peserta didik kelas VII SMPN 1 Semin tahun ajaran 2020/2021 sejumlah 145 peserta didik. Pembelajaran dengan penerapan blended learning melalui kegiatan tilik siswa mampu mengoptimalkan pembelajaran Prakarya. 90,3\% peserta didik lebih memahami materi budidaya tanaman sayuran melalui kegiatan tilik siswa selama pembelajaran jarak jauh. Sebanyak $92,4 \%$ peserta didik senang jika guru melakukan kegiatan tilik siswa selama pembelajaran jarak jauh sebagai pengganti tatap muka di sekolah. Kendala kegiatan tilik siswa ini antara lain tidak bisa menjangkau semua peserta didik karena keterbatasan waktu, keterbatasan kemampuan guru dan kondisi geografis tempat tinggal peserta didik yang jauh dari sekolah dan agak sulit dijangkau. Solusi yang diterapkan adalah pelaksanaan kegiatan bisa dilakukan di luar jam pelajaran, dilakukan secara berkala dan tidak hanya pada satu materi saja.

Kata kunci: pembelajaran prakarya, blended learning, tilik siswa
\end{abstract}

\section{Optimizing Distance Learning in Craft Learning with the Implementing Blended Learning through Student Inspection (Tilik Siswa) Activities}

\begin{abstract}
The aims of this best practice is to optimize distance learning through student inspection activities, evaluate the implementation of student inspection activities, and describe obstacles and solutions to distance learning through student inspection activities. The subjects of this best practice were the class VII students of VII SMPN 1 Semin Academic Year of 2020/2021 totaling 145 students. Learning with the application of blended learning through student inspection activities was able to optimize Craft learning. 90.3\% of students better understand the material of vegetable cultivation through student inspection activities during distance learning. As many as $92.4 \%$ of students were happy if the teacher conducted student inspection activities during distance learning as a substitute for face to face at school. The obstacles for the student inspection activities were the inabilities to reach all students due to time constraints, the limited ability of teachers and the geographical conditions where the students live which were far from school and rather difficult to reach. The solution applied was that the implementation of activities can be done outside of class hours, carried out regularly and not only on one material.
\end{abstract}

Keywords: craft learning, blended learning, student inspection

\section{Pendahuluan}

Sejak ditemukan kasus positif virus ini di Indonesia, Mendikbud Nadiem Makarim, mengeluarkan Surat Edaran Menteri Pendidikan dan Kebudayaan RI No 3 Tahun 2020 tanggal 9 Maret 2020 tentang 18 instruksi tindakan pencegahan perkembangan dan penyebaran virus tersebut di lingkungan satuan pendidikan. Salah satunya yaitu melaksanakan pembelajaran di rumah selama 14 hari. Langkah ini dinilai efektif untuk menjaga keselamatan para peserta didik dan tenaga kependidikan dari penularan virus Corona. Materi pembelajaran tetap sesuai dengan silabus yang sudah disederhanakan.
Pembelajaran ini disebut Pembelajaran Jarak Jauh (PJJ). Karakteristik pendidikan jarak jauh menurut Keegan dalam Warsita (2011: 24) adalah ada keterpisahan yang mendekati permanen antara tenaga pengajar dengan peserta didik dan seorang peserta didik dengan peserta didik lain selama program pendidikan, terdapat suatu institusi yang mengelola program pendidikan tersebut, pembelajaran memanfaatkan sarana komunikasi, baik berupa mekanis ataupun elektronis untuk menyampaikan bahan belajar, dan ada sarana komunikasi yang dua arah. 
Pola pembelajaran dalam PJJ juga berbeda. Jika dalam kegiatan belajar mengajar biasanya dilakukan dengan tatap muka antara peserta didik dan guru, tetapi tatap muka pada PJJ ini dengan bantuan teknologi. Peralatan teknologi yang digunakan antara lain laptop, TV, atau HP yang terhubung dengan internet. Ajang berdiskusi antara peserta didik dengan guru terhubung melalui aplikasi WhatsApp Grup (WAG) ataupun Google Classroom (GC). Pembelajaran ini dinamakan pembelajaran online atau daring (dalam jaringan).

PJJ di sekolah-sekolah di Provinsi Daerah Istimewa Yogyakarta diberlakukan mulai akhir Maret 2020 merujuk Surat Edaran Dinas Pendidikan, Pemuda, dan Olahraga DIY No. 421/02280 Tentang Pembelajaran Jarak Jauh Bagi Anak Sekolah Dalam Rangka Pencegahan Covid-19. Kemudian setelah itu pembelajaran jarak jauh ini masih diperpanjang sampai awal tahun 2021. PJJ secara online ini baru pertama kali dilaksanakan di SMPN 1 Semin. Banyak sekali hambatan dan tantangan yang dialami oleh peserta didik, pendidik dan tenaga kependidikan dalam proses pelaksanaannya. Hambatannya antara lain tidak semua tempat tinggal peserta didik mempunyai koneksi atau jaringan internet yang tidak stabil. Ada beberapa peserta didik yang harus berpindah ke tempat lain untuk mendapatkan sinyal HP. Hal ini menyebabkan peserta didik kesulitan mengakses materi dan mengirimkan tugas sekolah.

Tidak semua peserta didik mempunyai paket data atau kuota yang mencukupi untuk pembelajaran. Penghasilan orangtua yang tidak menentu setiap bulan dan ditambah dengan berkurangnya penghasilan karena dampak Covid-19 menyebabkan orangtua tidak bisa memberikan uang saku untuk pembelian pulsa atau kuota internet. Hambatan lain yaitu Terbatasnya sarana belajar peserta didik berupa android. Ada peserta didik yang belum mempunyai android sendiri, ada yang mempunyai android tapi rusak dan ada yang orangtuanya tidak mempunyai android.

PJJ menekankan pembelajaran peserta didik secara mandiri di rumah masing-masing. Peserta didik mengerjakan semua kegiatan antara lain belajar, menyelesaikan semua tugas dan bermain di rumah. Berbagai faktor yang terjadi di lingkungan rumah mempengaruhi lancar atau tidaknya PJJ di rumah.

Berubahnya pembelajaran tatap muka menjadi pembelajaran jarak jauh membuat guru kesulitan menerapkan model pembelajaran yang tepat. Salah satu kesulitannya adalah menerapkan pembelajaran dengan menggunakan praktikum atau proyek. Tidak adanya tatap muka dalam pembelajaran membuat kegiatan praktikum tidak bisa dilaksanakan secara optimal. Jika praktikum dilaksanakan di rumah, guru tidak bisa mengontrol proses dan hasil praktikum.

Hambatan yang lain adalah guru yang mengajar kelas 7 belum mengenal peserta didiknya secara mendetail. Hal ini karena kegiatan PPDB dan MOS pada tahun ajaran baru dilaksanakan secara online. Guru belum pernah bertemu peserta didik secara langsung dan hanya mengetahui nama peserta didik melalui grup WhatsApp atau Google Classroom. Selain itu juga terdapat peserta didik yang belum mengetahui nama guru dan mata pelajaran yang diampunya, sehingga diperlukan kegiatan tatap muka secara langsung antara guru dan peserta didik walaupun dilakukan hanya sebentar. Kegiatan belajar mengajar yang memadukan kegiatan online dan tatap muka disebut blended learning atau pembelajaran campuran.

Menurut Bonk \& Graham dalam Chaeruman (402: 2013), blended learning merupakan kombinasi pembelajaran yang berbeda dari dua model proses belajar dan mengajar, yaitu antara sistem pembelajaran tradisional yaitu tatap muka dengan pembelajaran yang memanfaatkan teknologi elektronik. Peralatan teknologi yang digunakan antara lain laptop, TV, atau HP yang terhubung dengan internet.

Materi dalam pelajaran Prakarya pada bab 4 adalah budidaya tanaman sayuran. Ada berbagai jenis tanaman sayuran yang mudah dibudidayakan di kecamatan Semin. Salah satunya adalah budidaya bawang merah. Sudah banyak masyarakat di kecamatan Semin yang membudidayakan bawang merah secara perseorangan ataupun berkelompok dalam Kelompok Wanita Tani (KWT). Dengan alasan tersebut, maka selama PJJ ini peserta didik perlu mendapatkan pengalaman belajar dan pembelajaran tentang kecakapan hidup dalam hal pembudidayaan tanaman sayuran.

Sesuai dengan uraian di atas, penulis memaparkan best practise tentang mengoptimalkan pempelajaran Prakarya selama PJJ dengan penerapan blended learning melalui program tilik siswa. Adapun perumusan masalah dari best practise ini adalah: 1) bagaimana mengoptimalkan pembelajaran Prakarya selama PJJ dengan penerapan blended learning melalui kegiatan tilik siswa?, 2) bagaimana pelaksanaan dan evaluasi pembelajaran Prakarya selama PJJ dengan penerapan blended learning melalui kegiatan tilik siswa? dan 3) apa kendala yang ditemui dan solusi yang bisa diterapkan dalam 
pembelajaran Prakarya selama PJJ dengan penerapan blended learning melalui kegiatan tilik siswa?

Tujuan kegiatan ini adalah untuk mengoptimalkan pembelajaran jarak jauh melalui kegiatan tilik siswa, mengevaluasi pelaksanaan kegiatan tilik siswa, dan mendeskripsikan kendala dan solusi pada pembelajaran jarak jauh melalui kegiatan tilik siswa.

Manfaat kegiatan tilik siswa ini antara lain: 1) bagi peserta didik yaitu mengoptimalkan pembelajaran peserta didik selama PJJ dan peserta didik bisa berkonsultasi secara langsung dengan guru mata pelajaran tentang kesulitan yang dihadapi selama PJJ, 2) bagi guru yaitu dapat menciptakan suasana belajar jarak jauh yang menyenangkan dan guru mengetahui kendala dan solusi dalam penerapan blended learning selama PJJ, 3) bagi sekolah yaitu bisa menggunakan best practise ini sebagai acuan untuk meningkatkan kualitas pendidikan selama PJJ dan pertimbangan untuk mengevaluasi proses pelaksanaan pembelajaran di sekolah, 4) bagi penulis lain yaitu menggunakan best practise ini untuk memperluas wawasan tentang penerapan model pembelajaran lain agar pembelajaran selama PJJ lebih optimal.

\section{Tinjauan Pustaka \\ Konseptual Pembelajaran Jarak Jauh}

Pembelajaran Jarak Jauh (PJJ) merupakan salah satu pilihan utama selama virus Corona masih terus menyebar di Indonesia. Selama pelaksanaan PJJ, guru dan peserta didik melakukan kegiatan belajar dan mengajar di tempat yang berbeda yaitu di rumah masingmasing. Otomatis kegiatan ini tidak dilakukan tatap muka secara langsung dan melalui alat perantara. Grenville Rumble (1989) mengatakan di proses pendidikan jarak jauh harus terdapat seorang guru, satu atau lebih, kurikulum yang bisa di terapkan oleh guru dan murid. Pendidikan jarak jauh merupakan sebuah pembelajaran dimana peserta didik secara fisik terpisah jarak dengan guru dan tidak terjadi tatap muka secara langsung (Pateni, 2016: 131). Pendidikan jarak jauh berfungsi memberikan layanan pendidikan kepada kelompok masyarakat yang tidak dapat mengikuti pendidikan secara tatap muka atau reguler (Sisdiknas UU pasal 31 tahun 2003).

Pelaksanaan PJJ ini pengajar dan pembelajar tidak harus berada dalam atu tempat yang sama. Pembelajar dapat menentukan sendiri kapan dan dimana waktu untuk belajarnya, sesuai dengan kecepatan dan gaya belajarnya (Munir, 2009: 9). Lebih lanjut Munir mengatakan pembelajaran bisa dilengkapi dengan penggunaan media yang memungkinkan terjadinya interaksi antara pengajar dan pembelajar. Hal ini bertujuan untuk mengatasi kendala keterbatasan tidak adanya tatap muka dan supaya proses pembelajaran menjadi lebih efektif dan efisien. Seiring dengan perkembangan teknologi yang semakin maju, media pembelajaran dibantu dengan penggunaan komputer, video, media non cetak, multimedia, dan internet.

\section{Blended learning}

Proses pembelajaran akan berjalan dengan baik apabila guru mampu menentukan dan menerapkan model pembelajaran yang sesuai. Menurut Aunurrahman (2013: 140), model pembelajaran merupakan kerangka konseptual yang menggambarkan prosedur yang sistematis dalam mengorganisasikan pengalaman belajar untuk mencapai tujuan belajar tertentu. Selain itu juga berfungsi sebagai pedoman untuk merencanakan dan melaksanakan aktivitas pembelajaran bagi para perancang pembelajaran dan para guru. Karena model pembelajaran memuat rencana yang akan dilakukan guru di dalam kelasnya maka keberhasilan proses pembelajaran sangat bergantung kepada model pembelajaran tersebut.

Ada banyak inovasi di bidang pendidikan kaitannya dengan pemilihan model pembelajaran. Salah satu contohnya adalah adanya model blended learning. Blended learning merupakan istilah yang berasal dari bahasa Inggris, yang terdiri dari dua suku kata yaitu blended dan learning. Blended artinya campuran atau kombinasi yang baik (Husamah, 2014: 11). Bielawski dan Metcalf dalam Husamah (2014: 16) mengemukakan bahwa blended learning merupakan sebuah konsep yang relatif baru dalam pembelajaran dimana pengajaran yang disampaikan menggabungkan pembelajaran online dan tatap muka. Pelaksanaan pembelajaran ini tetap dilakukan oleh instruktur atau pengajar.

Yusuf (2011: 232-242) mendefinisikan blended learning sebagai integrasi antara face to face dan online learning untuk membantu pengalaman kelas dengan mengembangkan teknologi informasi dan komunikasi. Berdasarkan beberapa pengertian di atas, blended learning adalah sebuah pembelajaran yang memadukan atau menggabungkan pembelajaran tatap muka (offline) dan pembelajaran secara online yang dibantu dengan media pembelajaran tertentu agar pembelajaran menjadi efektif dan menyenangkan. 
Ada beberapa model blended learning yang digunakan salah satunya adalah Project-Based Blended Learning. Kegiatan pada model ini berupa merancang, mengulang, dan menyelesaikan tugas pembelajaran berbasis proyek atau produk tertentu. Pembelajaran online berbentuk materi yang sudah disiapkan atau peserta didik mengakses secara mandiri pada sumber-sumber belajar yang dibutuhkan. Karakteristik utama dalam pembelajaran ini adanya penggunaan sumberdaya online untuk mendukung pembelajaran berbasis proyek. (Anonim, 2019). (https://maglearning.id/ 2019/02/03/model-model-penerapan-blendedlearning/)

\section{Kegiatan "Tilik Siswa"}

Tilik siswa merupakan istilah Jawa yang berasal dari kata tilik dan siswa. Menurut Poerwadarminta (1939: 606), tilik 1. menjang ing panggonaning lijan (wong lara), 2. diparani (didajohi) perloe disoemoeroepi kaanane. Jika diartikan, 1 . berkunjung ke orang sakit, 2 . bertamu untuk mengetahui keadaanya. Sumber lain menyatakan bahwa kata tilik mengandung arti melihat, menjenguk, bertandang (Jawa Timur bagian barat, Yogyakarta \& Jawa Tengah bagian timur), mencicipi (Jawa Timur) (https://www.maknaa.com/jawa-indonesia/tilik).

Siswa artinya murid atau peserta didik yang mengikuti proses pembelajaran. Jadi pengertian tilik siswa yaitu kegiatan bertamu, menjenguk atau bertandang ke rumah peserta didik untuk mengetahui keadaanya.

Kegiatan tilik siswa ini mengadopsi kegiatan home visit atau kunjungan rumah adalah yang sering dilakukan oleh guru Bimbingan Konseling. Home visit merupakan kegiatan yang mendukung proses bimbingan dan konseling. Hasil yang diperoleh dari home visit ini berupa data, keterangan, kemudahan serta komitmen bagi terentaskannya permasalahan klien melalui kunjungan ke rumahnya. Kegiatan ini memerlukan kerjasama yang penuh antara orang tua dan keluarga lainnya (Sukardi, 2008: 11). Menurut Prayitno home visit bisa bermakna upaya untuk mendeteksi kondisi keluarga yang berkaitan dengan permasalahan individu atau klien yang menjadi tanggung jawab pembimbing atau konselor dalam pelayanan bimbingan dan konseling. (Tohirin, 2014: 228).

\section{Pembahasan}

Strategi pemecahan masalah yang dilakukan adalah menerapkan model pembelajaran blended learning yaitu memadukan online (daring) dan offline (luring) berupa kegiatan home visit berupa kegiatan tilik siswa ke rumah peserta didik. Tahapan kegiatan ini adalah tahapan perencanaan, pelaksanaan dan evaluasi.

Tahapan perencanaan meliputi penentuan sasaran kegiatan, pemetaan Kompetensi Dasar, Indikator Pencapaian Kompetensi, perencanaan kegiatan pembelajaran, penyusunan perangkat pembelajaran dan instrumennya. Sasaran kegiatan adalah peserta didik kelas VII semester ganjil tahun pelajaran 2020/2021 di SMPN 1 Semin sebanyak 160 orang.

KD yang digunakan meliputi KD 3.1. memahami komoditas tanaman sayuran yang dapat dikembangkan sesuai kebutuhan wilayah setempat, 4.1. menentukan komoditas tanaman sayuran yang akan dibudidayakan sesuai kebutuhan wilayah, 3.2. memahami tahapan budi daya tanaman sayuran dan 4.2. mempraktikkan tahapan budi daya tanaman sayuran. Indikator Pencapaian Kompetensi yang dirumuskan yaitu peserta didik dapat menjelaskan jenis-jenis tanaman sayuran yang ada di lingkungan sekitar, mempraktikkan budidaya tanaman sayuran dengan media tanam pada lahan, polibag atau dengan modifikasi media tanam lain sesuai dengan kondisi lingkungan setempat, melakukan pemeliharaan tanaman sayuran pada lahan, polybag atau modifikasi media tanam dan mengevaluasi serta melaporkan kegiatan praktik dan pemeliharaan budidaya tanaman sayuran.

Kegiatan pembelajaran yang direncanakan sebanyak 2 kali pertemuan secara online dan 1 kali tatap muka melalui program tilik siswa. Penyusunan perangkat pembelajaran dan instrumennya yang digunakan meliputi RPP, Buku Siswa dan Buku Guru Prakarya kelas 7 Kurikulum 2013 edisi revisi 2017, android, alat dan bahan untuk praktikum budidaya bawang merah dan angket peserta didik. Tahapan pelaksanaan pembelajaran di tabel 1 .

Tabel 1. Tahapan pelaksanaan pembelajaran blended learning melalui kegiatan tilik siswa

\begin{tabular}{clll}
\hline Pertemuan ke & \multicolumn{1}{c}{ Tanggal } & \multicolumn{1}{c}{ Kegiatan } & \multicolumn{1}{c}{ Tempat } \\
\hline 1 (online) & 2 Oktober 2020 & Diskusi online dan literasi & Guru di sekolah, peserta didik di rumah \\
2 (online) & 9 Oktober 2020 & Diskusi online dan literasi & Guru di sekolah, peserta didik di rumah \\
3 (offline) & $\begin{array}{c}19-22 \text { Oktober } \\
\text { 2020 }\end{array}$ & Kunjungan ke rumah & Di rumah peserta didik \\
& & & \\
\hline
\end{tabular}


Pembelajaran online pelajaran Prakarya dengan menggunakan media sosial WhatsApp Group (WAG) "Espensa Berkarya". Hal ini karena media sosial ini lebih mudah digunakan oleh peserta didik dalam kehidupan sehari-hari. Kegiatan pada pertemuan pertama peserta didik membaca materi di buku paket Prakarya Semester 2 Kurikulum 2013. Langkah pembelajaran terdiri atas pendahuluan, kegiatan inti dan penutup. Setelah melakukan literasi ini peserta didik dapat menyebutkan tanaman sayuran yang berada di sekitar lingkungan dan mengelompokkan tanaman sayuran tersebut berdasarkan bagian yang dapat dimanfaatkan. Kegiatan pada pertemuan pertama ini diakhiri dengan pemberian tugas mengerjakan latihan soal melalui Google Form.

Kegiatan kedua masih menggunakan metode diskusi secara online melalui WAG. Kompetensi Dasar pada pertemuan kedua ini adalah KD 3.2. memahami tahapan budi daya tanaman sayuran dan 4.2. mempraktikkan tahapan budi daya tanaman sayuran. Setelah melakukan literasi digital melalui tayangan video tentang budidaya tanaman bawang merah ini adalah peserta didik dapat mempraktikkan budidaya tanaman sayuran, memelihara dan melaporkan kegiatan praktik dan pemeliharaan budidaya tanaman sayuran.

Setelah kegiatan pada pertemuan kedua, peserta didik kemudian melaksanakan praktikum mandiri menanam bawang merah sesuai dengan tutorial video. Peserta didik melakukan praktikum secara mandiri di rumah masingmasing. Peserta didik disarankan untuk mengerjakan praktikum ini bersama orangtua atau saudara di rumah. Guru memberikan kebebasan kepada peserta didik tentang aplikasi yang digunakan untuk membuat video ini. Hal ini karena tidak semua android peserta didik mempunyai aplikasi yang bagus untuk membuat video. Peserta didik bisa menggunakan KineMaster, Viva Video, Power Director atau aplikasi yang lainnya.

Pertemuan yang ketiga dilakukan secara offline (tatap muka) di rumah peserta didik. Guru melaksanakan kunjungan ke rumah peserta didik selama kurang lebih 20-30 menit. Pelaksanaan kegiatan tilik siswa ini secara individu dan berkelompok. Jika jarak beberapa rumah peserta didik berdekatan maka pembelajaran dilaksanakan secara berkelompok dan tetap memperhatikan protokoler kesehatan.

Pada gambar 1 memperlihatkan kegiatan yang dilakukan antara guru dan peserta didik, dalam bentuk kelompok ataupun individu.

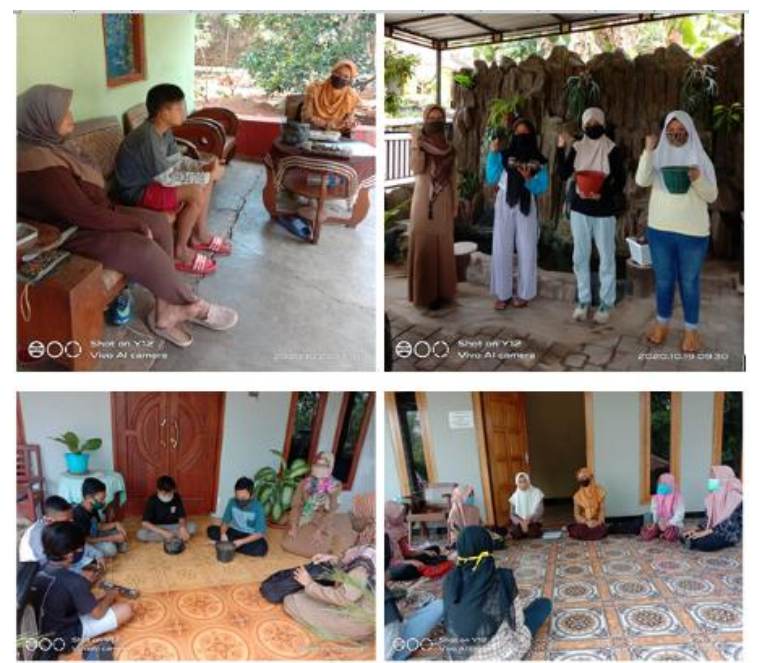

Gambar 1. Gambar kegiatan tilik siswa

Kegiatan yang dilakukan selama tilik siswa ini antara lain berdiskusi tentang kendala dalam pelaksanaan PJJ, mengecek tentang pelaksanaan praktikum budidaya bawang merah, dan berdiskusi tentang pembuatan tugas proyek video budidaya bawang merah.

Tahapan yang terakhir adalah evaluasi dan tindak lanjut. Blended learning merupakan suatu jenis model pembelajaran yang mengkombinasi atau memadukan antara pembelajaran tradisional dengan pembelajaran berbasis teknologi (komputer). Dari beberapa model pembelajaran PJJ salah satu yang diterapkan pada pembelajaran ini adalah model ProjectBased Blended Learning. Kegiatan siswa pada model ini adalah merancang sebuah proyek, mengulang, dan menyelesaikan tugas berdasarkan sumber belajar yang disampaikan guru secara online. Sumber belajar ini berupa video tentang budidaya bawang merah secara sederhana yang sudah diberikan pada pertemuan sebelumnya. Setelah siswa merancang proyek dan menyelesaikan tugas kemudian didiskusikan dengan guru pada saat tatap muka secara offline melalui kegiatan tilik siswa.

Pembelajaran online yang dilakukan sebelumnya mempelajari tentang berbagai macam tanaman sayuran dan tahapan budidaya tanaman sayuran bawang merah. Setelah mendapat pengetahuan tentang budidaya tersebut, peserta didik melanjutkan pembelajaran berbasis proyek yaitu praktikum budidaya bawang merah kemudian melaporkannya dalam bentuk video.

Subyek tanaman sayuran yang dibudidayakan adalah bawang merah. Bawang merah adalah salah satu tanaman sayuran yang dimanfaatkan umbinya. Tanaman ini sering sekali digunakan untuk memasak di rumah sehingga setiap peserta didik tidak kesulitan 
untuk mendapatkannya. Budidaya tanaman ini relatif mudah dilakukan.

Kegiatan tilik siswa ini merupakan kegiatan yang terinspirasi dari kegiatan home visit yang biasa dilakukan oleh guru Bimbingan Konseling. Tujuan guru melakukan kegiatan tilik siswa antara lain: 1) supaya peserta didik kelas 7 mengetahui dan mengenal guru yang mengampu mata pelajaran Prakarya, karena guru baru satu kali bertemu dengan peserta didik, 2) sebagai media guru untuk bersilaturahmi dengan orang tua/wali peserta didik sehingga guru bisa mengetahui pelaksanaan pembelajaran dan hambatan belajar peserta didik di rumah, 3) untuk mendapatkan referensi atau solusi yang tepat dalam pelaksanaan PJJ yang inovatif dan menyenangkan, 4) membantu kesulitan peserta didik dalam memahami materi pembelajaran selama PJJ, 5) mengetahui tahapan pelaksanaan praktek peserta didik di rumah, 6) membantu siswa menyelesaikan tugas proyek pembuatan video budidaya tanaman bawang merah, dan 7) memunculkan kedekatan secara psikologis dan emosional antara guru dengan peserta didik sehingga menciptakan hubungan timbal balik yang harmonis.

Banyak informasi yang didapatkan guru dari kegiatan tilik siswa ini, antara lain: 1) informasi dari orangtua tentang perkembangan belajar siswa di rumah; 2) kritik, keluhan dan saran tentang pelaksanaan PJJ secara umum; 3) respon yang baik dan dukungan dari orang tua/wali dengan adanya kegiatan tilik siswa. Setelah selesai kegiatan, siswa mengisi angket tentang pelaksanaan blended learning melalui kegiatan tilik siswa. Dari 160 peserta didik kelas 7 yang mengisi sebanyak 145 atau 91\%. Hasil angket peserta didik pada tabel 2 di bawah ini.

Hasil angket menyatakan bahwa selama PJJ ini $52,4 \%$ peserta didik merasa bosan jika pembelajaran hanya mengerjakan tugas secara teori saja. Selama ini tugas PJJ berupa materi yang dibagikan oleh guru kemudian diikuti dengan latihan soal. Ada juga tugas berupa meringkas materi kemudian dikirimkan secara online. Sebanyak $85,5 \%$ peserta didik lebih senang jika pembelajaran Prakarya selama PJJ berupa tugas proyek atau produk. Pemberian tugas berupa proyek akan membuat peserta didik lebih asyik mengerjakannya, kreatif dan inovatif dalam menyelesaikan tugas.

Sebanyak $88,3 \%$ peserta didik senang jika pembelajaran Prakarya selama PJJ dilaksanakan dengan model campuran (online dan tatap muka) berbasis proyek. Hal ini sesuai dengan pendapat Jusoff and Khodabandelou (2009: 82) dalam Syarif (2012: 238), blended learning bukan hanya mengurangi jarak yang selama ini ada diantara peserta didik dan guru namun juga meningkatkan interaksi diantara kedua belah pihak.

Blended learning melalui kegiatan tilik siswa mampu mengoptimalkan pembelajaran. 90,3\% peserta didik lebih memahami materi budidaya tanaman sayuran melalui kegiatan tilik siswa selama PJJ. Sebanyak 92,4\% peserta didik senang jika guru melakukan kegiatan tilik siswa selama PJJ sebagai pengganti tatap muka di sekolah.

Tabel 2. Hasil angket respon 145 siswa terhadap kegiatan tilik siswa

\begin{tabular}{|c|c|c|c|c|c|}
\hline \multirow{2}{*}{ No } & \multirow{2}{*}{ Pertanyaan } & \multicolumn{2}{|c|}{ Respon } & \multicolumn{2}{|c|}{ Persentase } \\
\hline & & $\mathrm{Ya}$ & Tidak & Ya & Tidak \\
\hline 1 & $\begin{array}{l}\text { Saya merasa bosan jika pembelajaran selama } \\
\text { mengerjakan tugas secara teori saja }\end{array}$ & 76 & 69 & 52.4 & 47.6 \\
\hline 2 & $\begin{array}{l}\text { Saya senang jika pembelajaran Prakarya selama PJJ berupa tugas } \\
\text { proyek atau produk }\end{array}$ & 124 & 21 & 85.5 & 14.5 \\
\hline 3 & $\begin{array}{l}\text { Saya senang jika pembelajaran Prakarya selama PJJ dilaksanakan } \\
\text { dengan model campuran (online dan tatap muka) }\end{array}$ & 128 & 17 & 88.3 & 11.7 \\
\hline 4 & $\begin{array}{l}\text { Saya dapat memperoleh pengalaman baru dalam pembelajaran } \\
\text { Prakarya selama PJJ dengan model pembelajaran campuran } \\
\text { berbasis proyek }\end{array}$ & 138 & 7 & 95,2 & 7,8 \\
\hline 5 & $\begin{array}{l}\text { Saya senang jika guru melakukan kegiatan "Tilik Siswa" selama PJJ } \\
\text { sebagai pengganti tatap muka di sekolah. }\end{array}$ & 134 & 11 & 92.4 & 7.6 \\
\hline 6 & $\begin{array}{l}\text { Melalui kegiatan "Tilik Siswa" selama PJJ saya lebih memahami } \\
\text { materi budidaya tanaman sayuran }\end{array}$ & 131 & 14 & 90.3 & 9.7 \\
\hline 7 & $\begin{array}{l}\text { Melalui kegiatan "Tilik Siswa" selama PJJ saya lebih tahu dan } \\
\text { mengenal guru yang mengajar mata pelajaran Prakarya }\end{array}$ & 138 & 7 & 95.2 & 4.8 \\
\hline 8 & $\begin{array}{l}\text { Saya menginginkan kegiatan "Tilik Siswa" selama PJJ ini juga } \\
\text { digunakan untuk materi pelajaran lain }\end{array}$ & 118 & 29 & 80 & 20 \\
\hline
\end{tabular}


Hal ini sesuai dengan pendapat Arifin (2010: 303) bahwa hasil belajar yang optimal dapat dilihat antara lain dari ketuntasan belajarnya, terampil dalam mengerjakan tugas yang diberikan serta peserta didik memiliki apresiasi yang bagus terhadap pelajaran.

Kegiatan tilik siswa mendapatkan respon yang bagus dari peserta didik. Sebanyak 92,4\% peserta didik senang jika guru melakukan kegiatan tilik siswa selama PJJ sebagai pengganti tatap muka di sekolah. Peserta didik juga bisa lebih mengenal guru yang mengajar mata pelajaran Prakarya. 80\% peserta didik menginginkan kegiatan tilik siswa selama PJJ ini juga digunakan untuk materi pelajaran lain.

Beberapa kendala yang dihadapi dalam kegiatan ini adalah belum bisa menjangkau semua peserta didik kelas 7 yang berjumlah 160 dengan berbagai alasan. Antara lain keterbatasan waktu, keterbatasan kemampuan guru dan kondisi geografis tempat tinggal siswa yang jauh dari sekolah dan agak sulit dijangkau.

Strategi yang bisa diterapkan untuk mengatasi kendala ini antara lain kegiatan ini bisa dilakukan di luar jam pelajaran sekolah dan dilakukan secara berkala. Bisa diadakan seminggu satu kali ataupun dua kali dan tidak hanya fokus pada satu materi saja. Guru juga bisa saling bekerjasama untuk melakukan kegiatan ini sehingga dengan satu kali kegiatan tidak hanya satu mata pelajaran saja yang bisa diajarkan. Dengan strategi seperti ini, diharapkan peserta didik tidak merasa dianak tirikan karena guru tidak berkunjung ke rumah.

Pembelajaran Prakarya selama PJJ dengan menerapkan blended learning melalui kegiatan tilik siswa mampu mengoptimalkan kegiatan belajar mengajar tentang budidaya tanaman bawang merah

Setiap model pembelajaran pasti akan ada sisi kekurangan dan kelebihannya. Tetapi pembelajaran blended learning selama PJJ melalui kegiatan tilik siswa diharapkan bisa dijadikan sebagai salah satu solusi pengganti tatap muka di sekolah.

Kegiatan tilik siswa selama PJJ sebaiknya sering dilakukan. Kegiatan ini mudah sekali untuk ditiru dan diterapkan pada pelajaran yang lain. Dengan kegiatan ini guru bisa mendapatkan secara langsung data yang akurat dan masalah yang dihadapi oleh peserta didik. Guru akan memperoleh hubungan timbal balik dan kerjasama yang baik dengan orang tua, sehingga diharapkan proses pembelajaran selama PJJ lebih optimal.

\section{Simpulan dan Saran}

Kesimpulan dari best practise ini adalah penerapan kegiatan tilik siswa selama PJJ dengan penerapan blended learning mampu mengoptimalkan pembelajaran Prakarya materi budidaya tanaman. Pelaksanaan kegiatan tilik siswa pada materi budidaya tanaman sayuran selama PJJ berjalan dengan baik. Kendala kegiatan ini antara lain tidak bisa menjangkau semua peserta didik karena keterbatasan waktu, keterbatasan kemampuan guru dan kondisi geografis tempat tinggal peserta didik yang jauh dari sekolah dan agak sulit dijangkau. Solusi yang diterapkan adalah pelaksanaan kegiatan bisa dilakukan di luar jam pelajaran, dilakukan secara berkala dan tidak hanya pada satu materi saja.

Rekomendasi dari hasil best practice ini yang diharapkan menjadi masukan adalah: 1) kepala sekolah diharapkan bisa membantu guru mengatasi permasalahan pembelajaran terutama selama PJJ, 2) guru diharapkan lebih optimal lagi dalam mempersiapkan kegiatan pembelajaran supaya proses pelaksanaannya dapat berjalan dengan baik dan sesuai dengan yang diharapkan, dan 3) guru diharapkan dapat meningkatkan kemampuannya pada proses perencanaan, pelaksanaan, dan evaluasi pembelajaran terutama selama PJJ.

\section{Daftar Pustaka}

Arifin, Zaenal. 2010. Evaluasi Pembelajaran. Bandung: Alfabeta.

Aunurrahman. (2013). Belajar Dan Pembelajaran. Bandung: Alfabeta

Chaeruman, Uwes Anis. (2013). Designing Blended Learning Model. Jurnal Teknodik. 17(4), 399-409. Retrieved from https://jurnalteknodik.kemdikbud.go.id/in dex.php/jurnalteknodik/article/view/577

https://maglearning.id/2019/02/03/modelmodel-penerapan-blended-learning/

https://www.maknaa.com/jawa-indonesia/tilik

Husamah. (2014). Pembelajaran Bauran (Blended Learning). Jakarta: Prestasi Pustaka Raya.

Munir. (2009). Pembelajaran Jarak Jauh Berbasis Teknologi Informasi Dan Komunikasi. Bandung: Alfabeta.

Pateni. (2016). Review Simonson, Smaldino Dan Zvacek For Teaching And Learning At A Distance Sixth Edition. Proceedings of International Research Clinic \& Scientific Publications Of Educational Technology. 130136 dari https://studylibid.com/doc/1077129/revie w-simonson--smaldino-dan-zvacek-forteaching-and-lea... Diunduh tanggal 1 Januari 2021 
Poerwadarminta, dkk. (1939). Baoesastra Djawa. Batavia. J.B. Woltrs' Uitgevers Maatschappij N.V Groningen.

Sukardi, Dewa Ketut. (2008). Proses Bimbingan Dan Konseling Di Sekolah. Jakarta: Rineka Cipta.

Surat Edaran Dinas Pendidikan, Pemuda, dan Olahraga DIY No. 421/02280 Tentang Pembelajaran Jarak Jauh Bagi Anak Sekolah Dalam Rangka Pencegahan Covid-19.

Syarif, I. (2012). Pengaruh Model Blended Learning Terhadap Motivasi dan Prestasi Belajar Siswa SMK. Jurnal Pendidikan Vokasi. 2(2), 234-249. Retrieved from https://journal.uny.ac.id/index.php/jpv/art icle/viewFile/1034/835.
Tohirin. (2014). Bimbingan dan Konseling di Sekolah dan Madrasah. Jakarta: Rajawali Press.

Undang-Undang Republik Indonesia Nomor 20 Tahun 2003 Tentang Sistem Pendidikan Nasional.

Warsita, Bambang. (2011). Pendidikan Jarak Jauh, Perencanaan, Pengembangan, Implementasi, dan Evaluasi Diklat. Bandung: Pt.Remaja Rosdakarya.

Yusuf, T, M. (2011). Mengenal Blended Learning. Jurnal Lentera Pendidikan. 14(2), 232-242. Retrieved from http://journal.uinalauddin.ac.id/index.php/lentera_pendidik an/article/view/3839 